DOI: 10.31866/2617-2674.4.1.2021.235104

\title{
Олександр Поліщук
}

доктор філософських наук, професор;

e-mail: Prokurator2007@ukr.net; ORCID: 0000-0002-9838-7105

Хмельницька гуманітарно-педагогічна академія, Хмельницький, Україна

Рецензія на навчальний посібник

О. В. Безручка, І. А. Гавран, С. В. Желєзняка, С. В. Котляр, Г. П. Чміль «Магістерські проєкти зі спеціальності "Аудіовізуальне мистецтво та виробництво" в Київському національному університеті культури і мистецтв» 1 і 2 тт.

\section{Александр Полищук}

доктор философских наук, профессор;

e-mail: Prokurator2007@ukr.net; ORCID: 0000-0002-9838-7105

Хмельницкая гуманитарно-педагогическая академия, Хмельницкий, Украина

\section{Рецензия на учебное пособие}

А. В. Безручко, И. А. Гавран, С. В. Железняка, С. В. Котляр, А. П. Чмиль «Магистерские проекты по специальности "Аудиовизуальное искусство и производство" в Киевском национальном университете культуры и искусств» 1 и 2 тт.

\section{Oleksandr Polishchuk}

Doctor of Philosophy, Professor;

e-mail: Prokurator2007@ukr.net; ORCID:0000-0002-9838-7105

Khmelnytsky Humanitarian-Pedagogical Academy, Khmelnitsky, Ukraine

Review of the textbook "Master's projects in "Audiovisual Art and Production" at the Kyiv National University of Culture and Arts" by 0 . V. Bezruchko, I. A. Gavran, S. V. Zhelezniak, S. V. Kotliar, H. P. Chmil, 1 and 2 vols. 

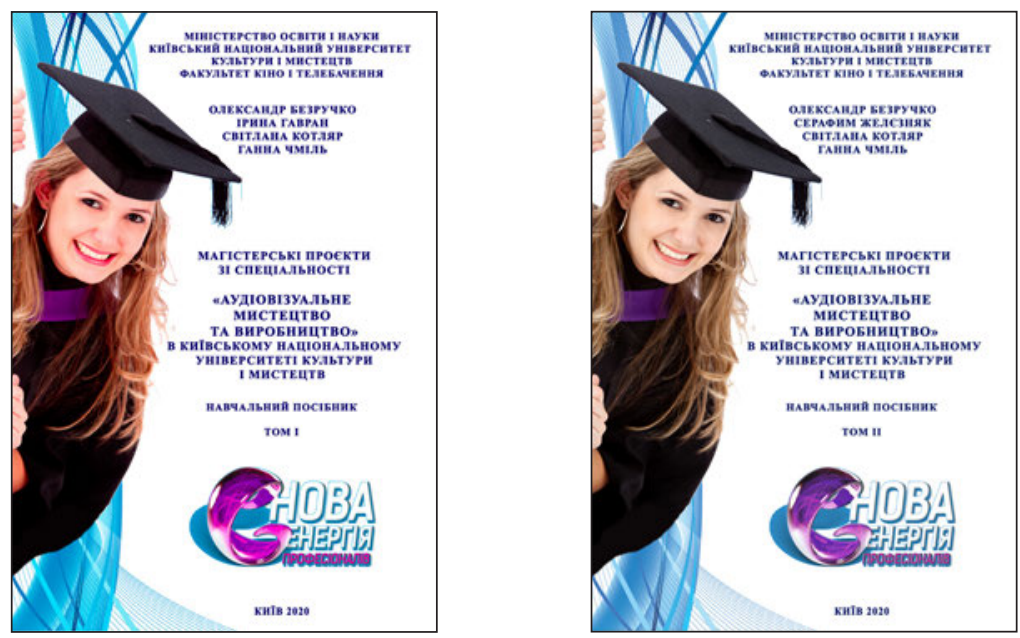

Безручко О. В., Гавран І. А., Котляр С. В., Чміль Г. П. Магістерські проєкти зі спеціальності «Аудіовізуальне мистецтво та виробництво» в Київському національному університеті культури і мистецтв : навч. посіб. Київ : Вид. центр КНУКіМ, 2020. Т. 1. 242 с.

Безручко О. В., Желєзняк С. В., Котляр С. В., Чміль Г. П. Магістерські проєкти зі спеціальності «Аудіовізуальне мистецтво та виробництво» в Київському національному університеті культури і мистецтв : навч. посіб. Київ : Вид. центр КНУКіМ, 2020. Т. 2. 259 с.

На сучасному етапі розвитку екранних мистецтв ключове місце належить формуванню теоретичних та практичних принципів мистецької освіти в Україні. Ці нагальні питання стають дедалі більш актуальними у галузі аудіовізуального мистецтва і виробництва. У цьому контексті запропонований навчальний посібник $€$ актуальним науковим виданням, який спрямований на оптимізацію фахової компетенції щодо підготовки та захисту магістерського творчого проєкту.

Слід зауважити, що сучасні перетворення у медійній сфері нині уже мало оцінювати як цікаві й своєрідні прояви екранної видовищної творчості, на них слід звернути увагу як на повноцінний науково-творчий процес, що і доводять автори представленого навчального доробку магістерського проєкту зі спеціальності «Аудіовізуальне мистецтво і виробництво» задля удосконалення набутих фахових знань, умінь та навичок майбутніх фахівців у процесі навчання.

З цієї точки зору, спроба поєднання теоретичної бази, спрямованої на розгляд конкретних науково-творчих питань реалізації практичного значення та визначення ролі і місця мистецької 


\section{REVIEWS. COMMENTS. CRITIQUES}

освіти у галузі аудіовізуального мистецтва і виробництва, роблять представлену роботу актуальним науковим виданням.

Цілком зрозуміло, що у даному матеріалі розглядаються науково-теоретичні та практичні аспекти щодо реалізації представленої проблеми, акцентується увага на спрямування, розкриття та обґрунтування методологічних засад теорії, історії та практики у галузі ауді- овізуального мистецтва і виробництва. Актуальність дослідження не викликає сумніву. Тема, що виноситься на обговорення, належить до найбільш фундаментальних проблем сучасної науки й соціальної практики.

Отже, видання з користю буде використане науковцями, викладачами та магістрантами мистецьких закладів вищої освіти у галузі аудіовізуального мистецтва і виробництва. 